\title{
Influence of Cover Crops on Management of Amaranthus Species in Glyphosate- and Glufosinate-Resistant Soybean
}

\author{
Mark M. Loux, Anthony F. Dobbels, Kevin W. Bradley, William G. Johnson, Bryan G. Young, \\ Douglas J. Spaunhorst, Jason K. Norsworthy, Matheus Palhano, and Lawrence E. Steckel*
}

A field study was conducted for the 2014 and 2015 growing season in Arkansas, Indiana, Illinois, Missouri, Ohio, and Tennessee to determine the effect of cereal rye and either oats, radish, or annual ryegrass on the control of Amaranthus spp. when integrated with comprehensive herbicide programs in glyphosate-resistant and glufosinate-resistant soybean. Amaranthus species included redroot pigweed, waterhemp, and Palmer amaranth. The two herbicide programs included were: a PRE residual herbicide followed by POST application of foliar and residual herbicide (PRE/POST); or PRE residual herbicide followed by POST application of foliar and residual herbicide, followed by another POST application of residual herbicide (PRE/POST/POST). Control was not affected by type of soybean resistance trait. At the end of the season, herbicides controlled 100 and $96 \%$ of the redroot pigweed and Palmer amaranth, respectively, versus 49 and $29 \%$ in the absence of herbicides, averaged over sites and other factors. The PRE/POST and PRE/POST/POST herbicide treatments controlled 83 and $90 \%$ of waterhemp at the end of the season, respectively, versus $14 \%$ without herbicide. Cover crop treatments affected control of waterhemp and Palmer amaranth and soybean yield, only in the absence of herbicides. The rye cover crop consistently reduced Amaranthus spp. density in the absence of herbicides compared to no cover treatment.

Nomenclature: Glufosinate; glyphosate; common waterhemp, Amaranthus rudis Sauer; Palmer amaranth, Amaranthus palmeri S. Wats.; redroot pigweed, Amaranthus retroflexus L.; Italian ryegrass, Lolium perenne L. ssp. multiflorum (Lam.) Husnot; cereal rye, Secale cereale L.; oat, Avena sativa L.; radish, Raphanus sativus; soybean, Glycine max L. Merr.

Key words: Cover crops, nonchemical weed control, weed suppression.

Amaranthus species have become the primary herbicide-resistant weeds in much of the corn (Zea mays L.), soybean, and cotton (Gossypium hirsutum L.) growing areas of the United States. Palmer amaranth and common waterhemp were recently ranked among the third and fourth most problematic weeds to manage in soybean and all crops, respectively, in the United States (Van Wychen 2016). These weeds are difficult to control, and often require complex herbicide programs, because of their propensity to evolve herbicide resistance and other biological characteristics. Characteristics of biology that contribute to these difficulties include high fecundity, plasticity, prolonged emergence period, high growth rate, adaptability to shading, and the ability to thrive in various environments and under various tillage systems (Hartzler et al. 2004; Jha, Norsworthy, Bridges, and Riley 2008; Jha, Norsworthy, Riley, and Bielenberg et al. 2008; Schwartz et al. 2016; Steckel et al. 2003; Ward et al. 2013; Webster and Grey 2015).

These characteristics, and widespread herbicide resistance, drive the need to use multiple applications and incorporate multiple-site-of-action herbicides for effective control of Palmer amaranth and common waterhemp (Anonymous 2013, 2016). The more effective herbicide programs include residual herbicides applied at the time of soybean planting

\footnotetext{
DOI: $10.1017 /$ wet.2017.30

* First and second authors: Professor and Research Specialist, Department of Horticulture and Crop Science, The Ohio State University, Columbus, OH 43221; Third author: Associate Professor, Plant Sciences Department, University of Missouri, Columbia, MO 65211; Fourth, fifth, and sixth authors: Professor, Associate Professor, and Graduate Research Assistant, Department of Botany and Plant Pathology, Purdue University, West Lafayette, IN 47907; Seventh and eighth authors: Professor and Graduate Research Assistant, Department of Crop, Soil, and Environmental Sciences, University of Arkansas, Fayetteville, AR 72701; Ninth author: Associate Professor, Department of Plant Sciences, University of Tennessee, Jackson, TN 38301. Corresponding author's E-mail: loux.1@osu.edu
} 
followed by a POST herbicide applied to small weeds in combination with a residual herbicide (Bell, Norsworthy, Scott, and Popp 2015). Including herbicides with residual activity in POST treatments can minimize the need for a subsequent application. Residual herbicides applied prior to or at planting are an essential component to minimize the variability in common waterhemp control that can occur with herbicide programs that use only POST herbicides (Legleiter et al. 2009). Full-season control of glyphosate-resistant Palmer amaranth exceeded 80\% only for herbicide programs where an effective PRE herbicide treatment was followed with a POST fomesafen application (Miller and Norsworthy 2016). Bell, Norsworthy, Scott, and Popp (2015) also determined that programs containing both PRE and POST herbicides provided better Palmer amaranth control than a POST-only program, and had much greater influence on control than did soybean row spacing or seeding rate.

New soybean trait technologies, such as resistance to auxinic and 4-hydroxyphenylpyruvate dioxygenase (HPPD)-inhibiting herbicides, do not necessarily allow for less comprehensive herbicide programs for common waterhemp or Palmer amaranth control (Meyer et al. 2015); rather, these traits allow PRE plus POST programs to be developed for effective control of both weeds over a wide range of geographies and environments. In the absence of PRE herbicide, a single POST application of dicamba controlled glyphosate-resistant common waterhemp less than 62\%, while sequential POST applications provided at least $72 \%$ control (Spaunhorst and Bradley 2013). In similar studies, dicamba applied POST once or twice controlled $88 \%$ to $89 \%$ of common waterhemp, demonstrating potential utility as a component of an integrated management program (Spaunhorst et al. 2014). Dicamba and 2,4-D contributed negligible residual control of Palmer amaranth and common waterhemp compared with treatments utilizing various combinations of isoxaflutole, $S$-metolachlor, flumioxazin, pyroxasulfone, and mesotrione (Meyer et al. 2016).

Common waterhemp and Palmer amaranth have demonstrated an ability to readily evolve resistance to herbicides that are used repeatedly, as well as to evolve multiple resistance. This ultimately limits the duration of effectiveness of any novel herbicide site of action introduced for control of populations already resistant to one or more sites of action.
It should be considered that, while resistance to group 4 and 27 herbicides may be novel in soybeans, these sites of action have previously been extensively used in corn for control of common waterhemp and Palmer amaranth. Rosenbaum and Bradley (2013) sampled common waterhemp populations from 144 fields in Missouri, and glyphosate resistance was more likely to occur where soybean was grown continuously and glyphosate was used exclusively for several seasons. Resistance to groups 2, 4, 5, 9, 14, and 27 occurs in common waterhemp in the United States as well as multiple resistance to various combinations of these sites of action (Bernards et al. 2012; Heap 2016). Similarly for Palmer amaranth, multiple resistance to groups $2,3,5,9,14$, and 27 has been confirmed.

Weed scientists acknowledge that reliance on herbicides almost exclusively for weed management in major field crops ultimately facilitates the evolution of resistance (Norsworthy et al. 2012). Ultimately, herbicide site-of-action diversification influences the rate at which resistance evolves, albeit resistance occurs more frequently for some weed species than for others. The difficulty in controlling Palmer amaranth and common waterhemp, and their propensity to readily evolve resistance, has driven research on the integration of chemical and nonchemical methods, with the ultimate goal of reducing the seedbank density. For example, in-season management of Palmer amaranth, and subsequent reduction in population density, was optimized through use of an effective PRE plus POST residual herbicide program in combination with integrated management strategies such as chaff removal from fields, cover crops, or weed seed burial during planting bed formation (Norsworthy et al. 2016).

Altering tillage or cultural factors can improve control of these weedy species in soybean and influence the emergence pattern and persistence of seed. Following a seed rain event, the germination and emergence of common waterhemp could be greater under no-till versus tilled conditions, albeit tillage increases the persistence of common waterhemp seed (Steckel et al. 2007). Leon and Owen (2006) observed four times greater waterhemp emergence under no-till compared with chisel plow or moldboard plow conditions, and also a longer period of emergence in the former. Similar results occurred in a study by Refsell and Hartzler (2009), along with 
the observation that common waterhemp seed remained near the surface in no-tillage, but was found primarily between 9- and $15-\mathrm{cm}$ depths in chisel plow conditions. The use of deep tillage following a rye cover crop or full-season wheat crop, in combination with PRE application of residual herbicides, resulted in greater control and reduced seed production of Palmer amaranth, and higher soybean yield (Bell et al. 2016). Comparing emergence with and without soybean canopy, Jha and Norsworthy (2009) observed a decline in Palmer amaranth emergence following the increased light interception that occurred after soybean canopy development. These results would appear to indicate a benefit to narrow row spacing that could facilitate earlier canopy development, although $>90 \%$ of the emergence occurred prior to canopy closure. Where PRE herbicides were used, no difference in Palmer amaranth emergence occurred among soybean seeding rates, although higher seeding rates reduced emergence in the absence of herbicide (Bell, Norsworthy, and Scott 2015). In one study of integrated approaches to common waterhemp control, the use of a comprehensive herbicide program (PRE fb POST plus residual), narrow soybean row spacing, and higher seeding rates resulted in the most effective control and reduction in density of common waterhemp, and highest soybean yields (Schultz et al. 2015).

The role that cover crops can have in management of Palmer amaranth and common waterhemp is also of great interest, as can be seen in the results of recent research. Full-season soybean production systems using a cereal rye cover crop or soybean double-cropped with wheat (Triticum aestivum L.) reduced Palmer amaranth emergence more than did systems without deep tillage, cereal rye, or wheat (DeVore et al. 2013). When used in combination with deep tillage, the cereal rye and wheat systems provided an additional reduction in emergence in one of two years compared with deep tillage alone. Crimson clover (Trifolium incarnatum L.) and hairy vetch (Vicia villosa Roth) controlled $62 \%$ and $58 \%$ of Palmer amaranth in the absence of herbicides, respectively, prior to POST herbicide application in corn, and reduced the growth rate of Palmer amaranth (Wiggins et al. 2015). Cereal rye and wheat provided more effective control of Palmer amaranth in cotton than did crimson clover or hairy vetch (Wiggins et al. 2016). These cereals or cereal-legume blends reduced Palmer amaranth emergence by half compared with no cover crops, but the combination of cover crops and
PRE herbicides did not result in adequate control. Some land grant universities are already making recommendations for the integration of specific cover crops in management programs for Palmer amaranth (L Steckel, personal communication). The objective of this multi-state project is to determine the effect of cereal rye and oat, radish, or Italian ryegrass, integrated with comprehensive herbicide programs, on crop yield and the control of Amaranthus species in glyphosateand glufosinate-resistant soybean.

\section{Materials and Methods}

A field study was conducted at a total of 13 sites in Arkansas, Indiana, Illinois, Missouri, Ohio, and Tennessee over three years, starting in the fall of 2013 and ending in the fall of 2015 (Table 1). The study was conducted over two seasons in areas with known infestations of redroot pigweed (two sites), common waterhemp (five sites), or Palmer amaranth (six sites). The common waterhemp and Palmer amaranth populations were resistant to glyphosate, while redroot pigweed populations were glyphosatesensitive. Treatments were arranged in a split-splitplot design with four replications. The main plot was cover crop, and the split plot was soybean herbicideresistance trait, and the split-split plot was herbicide treatment. The two cover crops were cereal rye and a second cover crop that varied by site among Italian ryegrass, spring oat, or forage radish (Table 2). In addition, a no-cover treatment was included at all sites. Across all sites, cover crops were seeded from September 23 to November 20 in 2013 and from September 11 to October 9 in 2014, using appropriate seeding rates based on local recommendations. Seeding rates ranged from 67 to $134 \mathrm{~kg} \mathrm{ha}^{-1}$ for cereal rye, 67 to $100 \mathrm{~kg} \mathrm{ha}^{-1}$ for oat, 6.6 to $11 \mathrm{~kg} \mathrm{ha}^{-1}$ for radish, and $22 \mathrm{~kg} \mathrm{ha}^{-1}$ for Italian ryegrass. The tillage and cropping situation into which cover crops were planted included no-till and tilled sites, with previous crop of silage or field corn (Zea mays L.), cotton (Gossypium hirsutum L.), or soybean. Cover crops were seeded with a drill at all sites.

Glyphosate- and glufosinate-resistant soybean of appropriate maturity for the site was planted the following spring at a row spacing ranging from 19 to $96 \mathrm{~cm}$ (Table 1). The soybeans were planted in May, with the exception of the Missouri site in 2015, where planting was delayed until June 25 (Table 2). Winter conditions killed the spring oat and forage 
Table 1. Site description information for 2014 and 2015 cover crop experiments. Abbreviations: OM, organic matter; CEC, cation exchange capacity; Gly-R, glyphosate-resistant; Glu-R, glufosinate-resistant.

\begin{tabular}{|c|c|c|c|c|c|c|c|c|c|}
\hline \multirow[b]{2}{*}{ Test site } & \multirow[b]{2}{*}{ Year } & \multicolumn{4}{|c|}{ Soil properties } & \multicolumn{2}{|c|}{ Soybean variety } & \multirow[b]{2}{*}{ Row spacing } & \multirow[b]{2}{*}{ Weed } \\
\hline & & Texture & $\% \mathrm{OM}$ & $\mathrm{pH}$ & CEC & Gly-R & Glu-R & & \\
\hline & & & & & & & & $(\mathrm{cm})$ & \\
\hline \multirow[t]{2}{*}{ AR } & 2014 & Silt loam & 2.0 & 6.5 & 13.1 & AG4933 & P95L01 & 96 & AMAPA \\
\hline & 2015 & Silt loam & 2.0 & 5.5 & 13.1 & AG4933 & P95L01 & 91 & AMAPA \\
\hline \multirow[t]{2}{*}{ IN } & 2014 & Silt loam & 3 & 6.7 & 16.3 & AG2933 & BE2984L & 38 & AMAPA \\
\hline & 2015 & Silt loam & 2.9 & 6.9 & 12.3 & AG2933 & BE2984 & 38 & AMAPA \\
\hline \multirow[t]{3}{*}{ IL } & 2014 & Silt loam & 2.1 & 6.9 & 12.7 & AG3832 & HS42L22 & 76 & AMATA \\
\hline & $2015 A$ & Silt loam & 2.1 & 6.9 & 12.4 & AG3832 & HS42L22 & 19 & AMATA \\
\hline & $2015 B$ & Silt loam & 2.3 & 6.7 & 9.8 & AG3832 & HS42L22 & 19 & AMATA \\
\hline \multirow[t]{2}{*}{$\mathrm{MO}$} & 2014 & Silty clay loam & 1.1 & 6.8 & - & AG3832 & LL3579 & 38 & AMATA \\
\hline & 2015 & Silt loam & 2.3 & 6.5 & 9.2 & AG3832 & LL3579 & 76 & AMATA \\
\hline \multirow[t]{2}{*}{$\mathrm{OH}$} & 2014 & Silty clay loam & 3.5 & 6.6 & 22 & P35T58R & P34T35L & 38 & AMARE \\
\hline & 2015 & Silty clay loam & 1.7 & 7 & 15 & P35T97R2 & CZ3841LL & 38 & AMARE \\
\hline \multirow[t]{2}{*}{$\mathrm{TN}$} & 2014 & Silt loam & 1.7 & 6.4 & - & AG4633 & LL4650 & 38 & AMAPA \\
\hline & 2015 & Silt loam & 1.7 & 6.4 & - & AG4633 & LL4850 & 38 & AMAPA \\
\hline
\end{tabular}

radish without need for additional herbicides. The entire experimental area was treated with glyphosate and $2,4-\mathrm{D}$ ester at 0.84 and $0.56 \mathrm{~kg}$ ae $\mathrm{ha}^{-1}$, respectively, between late March and mid-May, to terminate the cereal rye, Italian ryegrass, and emerged weeds (Table 2). Cover crop termination timing ranged from 0 to 6 weeks before planting.

The herbicide treatments in this study represent the comprehensive approach required for Palmer amaranth control. Treatments within each combination of cover crop and soybean herbicideresistance trait included 1) nontreated; 2) PRE/ POST, consisting of PRE residual herbicide followed by POST application of foliar and residual herbicide $21 \mathrm{~d}$ after planting (DAP); and 3) PRE/POST/ POST, consisting of PRE residual herbicide followed by POST application of foliar and residual herbicide 21 DAP, followed by another POST application of residual herbicide $42 \mathrm{DAP}$. At some sites, the PRE herbicides were applied with the glyphosate and 2,4-D, while at other sites these were separated by a month or more, with PRE herbicide always applied at the time of soybean planting.

The PRE residual herbicide was flumioxazin applied at $90 \mathrm{~g}$ ai ha ${ }^{-1}$. The first POST treatment in glyphosate-resistant soybean consisted of glyphosate at $0.84 \mathrm{~kg} \mathrm{ha}^{-1}$, fomesafen at $0.35 \mathrm{~kg} \mathrm{ai} \mathrm{ha}^{-1}$, and metolachlor at $1.4 \mathrm{~kg}$ ai ha ${ }^{-1}$. This treatment included ammonium sulfate at $2 \%(\mathrm{w} / \mathrm{v})$ (Winfield Solutions LLC, St. Paul, MN) and methylated seed oil at $1 \%$ (v/v) (Helena Chemical Company, Collierville, TN).
The first POST treatment in glufosinate-resistant soybean consisted of glufosinate and metolachlor at 0.65 and $1.4 \mathrm{~kg}$ ai ha ${ }^{-1}$, respectively, and also included ammonium sulfate at $2 \%(\mathrm{w} / \mathrm{v})$. The second POST treatment in both systems was acetochlor at $1.3 \mathrm{~kg}$ ai ha ${ }^{-1}$. Herbicides were applied in a volume of $143 \mathrm{~L} \mathrm{ha}^{-1}$. Other application parameters varied among sites based upon standard practices.

Control of Amaranthus species was evaluated, and population density measured at the time of each POST application and just prior to soybean harvest. Control was evaluated using a scale of 0 to 100 , where 0 represented no control and 100 represented complete control (no plants evident). Population density was measured 21 DAP by counting plants within $0.5-\mathrm{m}^{2}$ quadrants placed at two locations in each plot. These $0.5-\mathrm{m}^{2}$ areas were marked and used for subsequent measurements at $42 \mathrm{DAP}$ and preharvest. At maturity, soybean was mechanically harvested, and seed yield measured and adjusted to $13 \%$ moisture for analysis. Data were combined among the sites for each Amaranthus species, and analyzed by the SAS GLIMMEX procedure for mixed models. Means were separated using Fisher's protected LSD at the 95\% level of probability. Cover crop biomass was not measured.

\section{Results and Discussion}

The herbicide programs effectively controlled redroot pigweed and Palmer amaranth, regardless of 
Table 2. Cover crop, herbicide application, and soybean planting date information.

\begin{tabular}{|c|c|c|c|c|c|c|c|}
\hline \multirow[b]{2}{*}{ Test site } & \multirow[b]{2}{*}{ Year } & \multicolumn{2}{|c|}{ Cover crop ${ }^{\mathrm{a}} /$ seed rate $\left(\mathrm{kg} \mathrm{ha}^{-1}\right)$} & & \multirow[b]{2}{*}{ Cover plant } & \multirow[b]{2}{*}{ Cover termination } & \multirow[b]{2}{*}{ Soybean plant $^{\mathrm{b}}$} \\
\hline & & Cover 1 & Cover 2 & & & & \\
\hline AR & 2014 & SECCE/90 & RAPSS/11 & & Sept 28 & May 1 & May 23 \\
\hline \multirow[t]{2}{*}{ IN } & 2014 & SECCE/90 & LOLMG/22 & & Sept 27 & May 20 & May 27 \\
\hline & 2015 & SECCE/90 & LOLMG/22 & & Sept 19 & May 6 & May 18 \\
\hline \multirow[t]{2}{*}{ IL } & 2014 & SECCE/134 & AVESA/101 & & Sept 23 & April 18 & May 6 \\
\hline & $2015 B$ & SECCE/134 & AVESA/101 & & Sept 30 & April 18 & May 4 \\
\hline \multirow[t]{2}{*}{$\mathrm{MO}$} & 2014 & SECCE/112 & RAPSS/6.7 & & Nov 20 & May 16 & May 23 \\
\hline & 2015 & SECCE/112 & RAPSS/6.7 & & Sept 11 & May 27 & June 25 \\
\hline \multirow[t]{2}{*}{$\mathrm{OH}$} & 2014 & SECCE/101 & AVESA/67 & & Oct 11 & April 17 & May 5 \\
\hline & 2015 & SECCE/101 & AVESA/67 & & Oct 9 & April 14 & May 4 \\
\hline $\mathrm{TN}$ & 2014 & SECCE/67 & AVESA/67 & & Sept 23 & March 20 & May 12 \\
\hline
\end{tabular}

a Cover crop abbreviations: AVESA, spring oat; LOLMG, Italian ryegrass; RAPSS, forage radish; SECCE, cereal rye.

b PRE herbicides were applied between $29 \mathrm{~d}$ before and $1 \mathrm{~d}$ after soybean planting.

the presence or absence of a cover crop, and they were only slightly less effective on common waterhemp. Averaged over cover crops and soybean resistance traits, plots that received either POST herbicide treatment had $100 \%$ control of redroot pigweed at the end of the season, while the plots without herbicide averaged $49 \%$ control. Control of Palmer amaranth control exceeded $96 \%$ for either POST treatment, but was only $29 \%$ in the absence of herbicides. The PRE/POST and PRE/POST/ POST treatments controlled $83 \%$ and $90 \%$ of common waterhemp at the end of the season, respectively, while no herbicide treatment resulted in $14 \%$ control. Differences among cover crop treatments were observed only in the absence of herbicides, and the magnitude of these differences varied among species and evaluation timings.

The control and population density of redroot pigweed was affected only by the herbicide factor throughout the season, and this was due to differences between herbicide treatments and the nontreated control. There was no difference between the PRE/ POST and PRE/POST/POST treatments, and no interactions with cover crop and soybean herbicide resistance trait. The herbicides provided $81 \%$ to $85 \%$ control of redroot pigweed at $21 \mathrm{DAP}, 95 \%$ at 42 DAP, and $100 \%$ at harvest, while control in the nontreated plots ranged from $0 \%$ to $49 \%$ when averaged over cover crops and soybean herbicide resistance trait (data not shown). Population density for the PRE/POST and PRE/POST/POST treatments averaged 8,1 , and 0 plants $\mathrm{m}^{-2}$ at $21 \mathrm{DAP}$, $42 \mathrm{DAP}$, and harvest, respectively, and 25, 18, and 2 plants $\mathrm{m}^{-2}$ in the nontreated plots (data not shown). Soybean grain yield was higher where herbicides were used compared with the nontreated plots, at 4,170 to 4,430 versus $2,080 \mathrm{~kg} \mathrm{ha}^{-1}$ (data not shown).

Herbicides controlled at least $92 \%$ of the Palmer amaranth throughout the season, while control in the absence of herbicides ranged from $16 \%$ to $29 \%$, averaged over cover crop, soybean herbicideresistance trait, and site. There was a consistent interaction between cover crop and herbicide, which reflected the higher control provided by cereal rye compared with a different cover crop or no cover crop, in the absence of herbicides (Figure 1). The cereal rye controlled $34 \%$ to $49 \%$ of the Palmer amaranth over the season, while control did not exceed $22 \%$ for the other cover crop species. At 21 DAP, the other cover crops provided higher control than did the no-cover treatment, $16 \%$ versus $5 \%$, although differences at this level of control are of little biological importance. Population density at 21 DAP was affected only by herbicide, ranging from 7 to 8 plants $\mathrm{m}^{-2}$ where herbicide was applied versus 25 plants $\mathrm{m}^{-2}$ for the nontreated, averaged over other factors (data not shown). A similar interaction occurred for population density at $42 \mathrm{DAP}$ and harvest (Figure 2). Density was uniformly low where herbicide was applied, with no difference between PRE/POST and PRE/POST/POST herbicide treatments or among cover crops. In the absence of herbicides, density was 

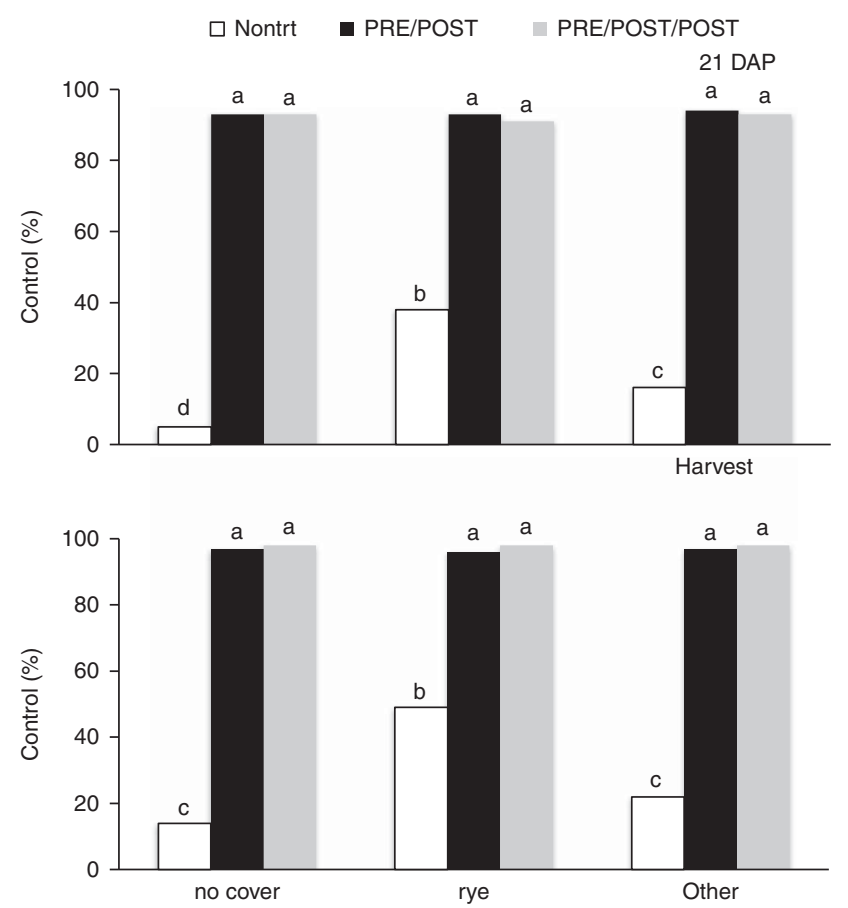

Figure 1. Effect of cover crop and herbicide treatment on control of Palmer amaranth $21 \mathrm{~d}$ after planting and at harvest, averaged over soybean resistance trait and site. Means with the same letter are not different based on Fisher's protected LSD (0.05).

approximately 50\% lower for cereal rye versus the other cover crops or no cover treatments. These differences in control and density were reflected in soybean yields, for which there was an interaction between herbicide and cover crop. Soybean grain yield was highest where herbicides were applied, with no difference between the PRE/POST and PRE/POST/POST treatments regardless of cover crop (data not shown). Differences among cover crops occurred in the absence of herbicide, in the following order: cereal rye $>$ other cover crop $>$ no cover, at 2,820, 2,280, and $1,880 \mathrm{~kg} \mathrm{ha}^{-1}$, respectively.

As was seen with Palmer amaranth, control of common waterhemp at 21 and $42 \mathrm{DAP}$ did not vary between the PRE/POST and PRE/POST/POST treatments, but control did not exceed $88 \%$ (Figure 3). An interaction between cover crops and herbicide treatment reflected the higher control from cereal rye versus the other cover crop and no cover treatments in the absence of herbicides. The cereal rye controlled $47 \%$ and $19 \%$ of the common waterhemp at 21 and $42 \mathrm{DAP}$, respectively, but control did not exceed $13 \%$ for the other cover crop treatments. There was no interaction among factors at harvest (Figure 4). Averaged over other factors, the
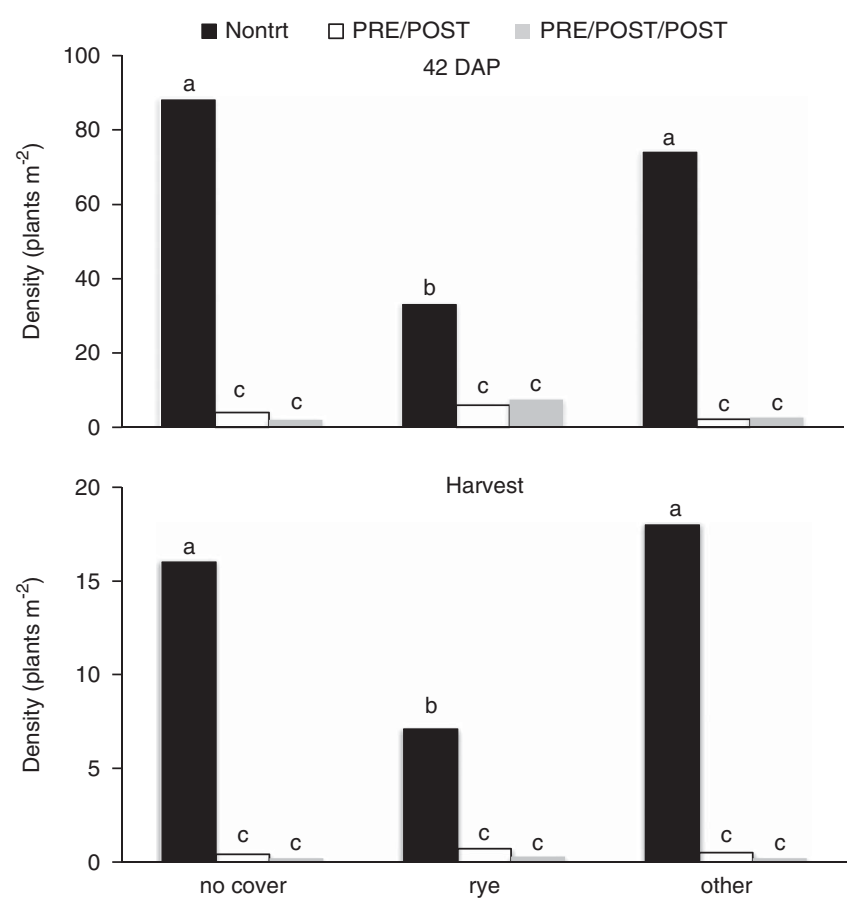

Figure 2. Effect of cover crop and herbicide treatment on population density of Palmer amaranth $42 \mathrm{~d}$ after planting and at harvest, averaged over soybean resistance trait and site. Means with the same letter are not different based on Fisher's protected LSD (0.05).

cereal rye and other cover crops provided similar levels of control, $63 \%$ to $66 \%$, versus $58 \%$ for the no cover treatment (data not shown). In the absence of herbicide, control did not exceed 19\% for any cover crop treatment. Unlike the Palmer amaranth results, the PRE/POST/POST treatment was more effective than the PRE/POST treatment at the end of the season (Figure 4). The PRE/POST/POST and PRE/ POST treatments controlled $90 \%$ and $83 \%$ of the common waterhemp, respectively, averaged over other factors, while control in the nontreated plots was $13 \%$. This was also reflected by population density results, where the PRE/POST/POST resulted in lower density than the PRE/POST treatment at harvest, 2 versus 7 plants $\mathrm{m}^{-2}$. Density was similar between the two herbicide treatments 21 and 42 DAP, ranging from 111 to 125 plants $\mathrm{m}^{-2}$ (data not shown).

Control of common waterhemp was generally lower throughout the season compared with control of redroot pigweed or Palmer amaranth. The more comprehensive herbicide treatment resulted in greater common waterhemp control at harvest, which was not observed for the other species. These differences reflect the apparent additional control of 

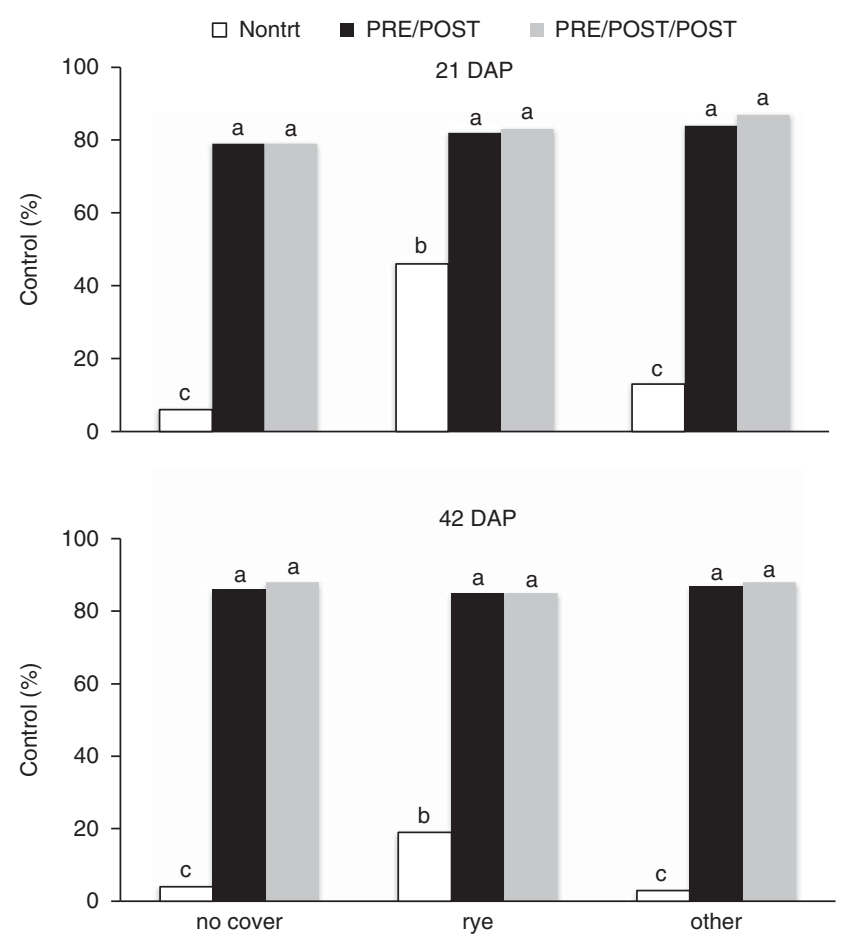

Figure 3. Effect of cover crop and herbicide treatment on control of common waterhemp 21 and $42 \mathrm{~d}$ after planting, averaged over soybean resistance trait and site. Means with the same letter are not different based on Fisher's protected LSD (0.05).

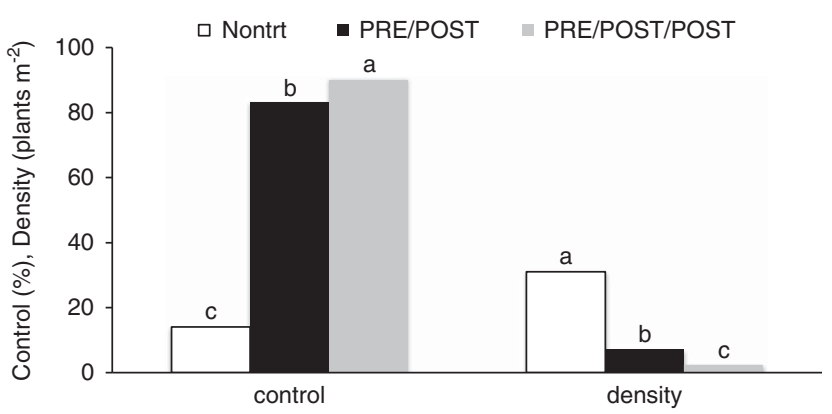

Figure 4. Effect of herbicide treatment on common waterhemp control and population density at harvest, averaged over cover crop treatment, herbicide resistance trait, and site. Means with the same letter are not different based on Fisher's protected LSD (0.05).

late-emerging common waterhemp plants from the second POST application of acetochlor. This effect, and the overall lower common waterhemp control compared to the other species, may have been partly due to the higher population densities of common waterhemp. The density of common waterhemp at 21 and 42 DAP in the no-cover treatments ranged from 650 to 820 plants $\mathrm{m}^{-2}$, but ranged from only

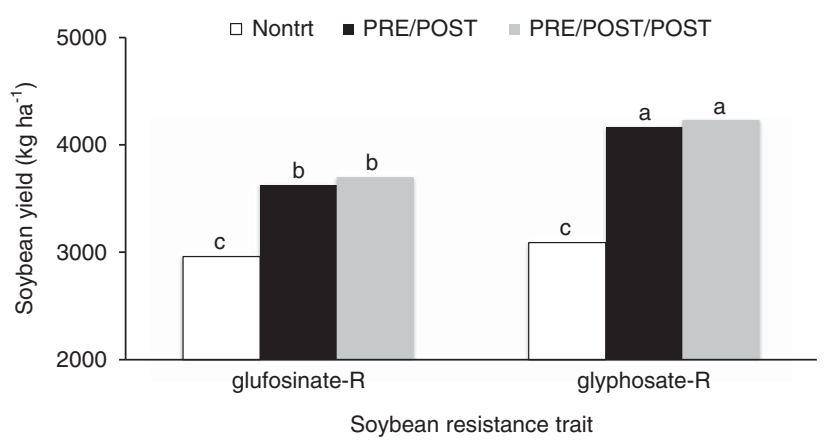

Figure 5. Effect of herbicide treatment on soybean seed yield, averaged over cover crop treatment and common waterhemp site. Means with the same letter are not different based on Fisher's protected LSD (0.05).

15 to 23 and 80 to 88 plants $\mathrm{m}^{-2}$ for redroot pigweed and Palmer amaranth, respectively (data not shown). The end-of-season density was lower for all three species, due to the combined effect of herbicide treatments and the soybean canopy, but common waterhemp density was still approximately two and sixteen times higher than Palmer amaranth and redroot pigweed density in nontreated, no cover crop areas.

Soybean grain yields at common waterhemp sites showed similar trends to those at sites infested with other species, in that the lack of herbicide resulted in lower yield compared with the two herbicide treatments (Figure 5). However, an interaction between herbicide and soybean herbicide-resistance trait occurred, and in the presence of herbicides, the glyphosate-resistant soybean yields were higher than the glufosinate-resistant soybean yields. Since there were no differences in control between the soybean herbicide-resistance traits, this would appear to reflect the higher yield potential for the glyphosate-resistant soybean cultivars used here, in comparison to the glufosinate-resistant cultivars. In this study, there was no attempt made to control variation in yield potential between the two selected soybean cultivars. The differences in yield here thus has little meaning except to show the importance of effective weed management on obtaining maximum yields.

The results of this study showed that cereal rye has more potential than the other cover crops tested (spring oat, forage radish, and Italian ryegrass) to contribute to control of Amaranthus species when integrated into a comprehensive herbicide program. The presence of the cover crops did not influence control with the herbicide programs used here. 
However, the control contributed by the cover crop could presumably improve control where the population density of the weeds was high, or where environmental conditions reduce herbicide effectiveness. Where control from the cover crops helps to reduce the population density within the first month or so following soybean planting, there would presumably be reduced selection for resistance to the herbicides used in POST treatments.

\section{Acknowledgements}

The authors thank all of the graduate and undergraduate research assistants, as well as the research support staff, who helped with implementation, maintenance, and data collection of this project at each site. This research was funded by the United Soybean Board. Salaries and research support were provided by state and federal funds appropriated to the Ohio Agricultural Research and Development Center, grant number $\mathrm{OHO} 01302$, journal article HCS17-03.

\section{Literature Cited}

Anonymous (2013) Palmer Amaranth Management in Soybeans. USB Take Action fact sheet. http://takeactiononweeds.com. Accessed January 7, 2017

Anonymous (2016) Waterhemp Management in Soybeans. USB Take Action fact sheet. http://takeactiononweeds.com. Accessed January 7, 2017

Bell HD, Norsworthy JK, Scott RC (2015) Effect of drill-seeded soybean density and residual herbicide on Palmer amaranth (Amaranthus palmeri) emergence. Weed Technol 29:697-706

Bell HD, Norsworthy JK, Scott RC (2016) Integrating cereals and deep tillage with herbicide programs in glyphosate- and glufosinate-resistant soybean for glyphosate-resistant Palmer amaranth management. Weed Technol 30:85-98

Bell HD, Norsworthy JK, Scott RC, Popp M (2015) Effect of row spacing, seeding rate, and herbicide program in glufosinateresistant soybean on Palmer amaranth management. Weed Technol 29:390-404

Bernards ML, Crespo RJ, Kruger GR, Gaussoin R, Tranel PJ (2012) A waterhemp (Amaranthus tuberculatus) population resistant to 2,4-D. Weed Sci 60:379-384

DeVore JD, Norsworthy JK, Brye KR (2013) Influence of deep tillage, a rye cover crop, and various soybean production systems on Palmer amaranth emergence in soybean. Weed Technol 27:263-270

Hartzler RG, Battles BA, Nordby D (2004) Effect of common waterhemp (Amaranthus rudis) emergence date on growth and fecundity in soybean. Weed Sci 52:242-245

Heap I (2016) International Survey of Herbicide-Resistant Weeds. http://weedscience.org. Accessed January 7, 2017
Jha P, Norsworthy JK (2009) Soybean canopy and tillage effects on emergence of Palmer amaranth (Amaranthus palmeri) from a natural seed bank. Weed Sci 57:644-651

Jha P, Norsworthy JK, Bridges W Jr, Riley MB (2008) Influence of glyphosate timing and row width on Palmer amaranth (Amaranthus palmeri) and pusley (Richardia spp.) demographics in glyphosate-resistant soybean. Weed Sci 56:408-415

Jha P, Norsworthy JK, Riley MB, Bielenberg DG, Bridges W Jr (2008) Acclimation of Palmer amaranth (Amaranthus palmeri) to shading. Weed Sci 56:729-734

Legleiter TR, Bradley KW, Massey RE (2009) Glyphosate-resistant waterhemp (Amaranthus rudis) control and economic returns with herbicide programs in soybean. Weed Technol 23:54-61

Leon RG, Owen MDK (2006) Tillage systems and seed dormancy effects on common waterhemp (Amaranthus tuberculatus) seedling emergence. Weed Sci 54:1037-1044

Meyer CJ, Norsworthy JK, Young BG, Steckel LE, Bradley KW, Johnson WG, Loux MM, Davis VM, Kruger GR, Bararpour MT, Ikley JT, Spaunhorst DJ, Butts TR (2015) Herbicide program approaches for managing glyphosate-resistant Palmer amaranth (Amaranthus palmeri) and waterhemp (Amaranthus tuberculatus and Amaranthus rudis) in future soybean-trait technologies. Weed Technol 29:716-729

Meyer CJ, Norsworthy JK, Young BG, Steckel LE, Bradley KW, Johnson WG, Loux MM, Davis VM, Kruger GR, Bararpour MT, Ikley JT, Spaunhorst DJ, Butts TR (2016) Early-season Palmer amaranth and waterhemp control from preemergence programs utilizing 4-hydroxyphenylpyruvate dioxygenase-inhibiting and auxinic herbicides in soybean. Weed Technol 30:67-75

Miller MR, Norsworthy JK (2016) Evaluation of herbicide programs for use in a 2,4-D-resistant soybean technology for control of glyphosate-resistant Palmer amaranth (Amaranthus palmeri). Weed Technol 30:366-376

Norsworthy JK, Korres NE, Walsh MJ, Powles SB (2016) Integrating herbicide programs with harvest weed seed control and other fall management practices for the control of glyphosate-resistant Palmer amaranth (Amaranthus palmeri). Weed Sci 64:540-550

Norsworthy JK, Ward SM, Shaw DR, Llewellyn RS, Nichols RL, Webster TM, Bradley KW, Frisvold G, Powles SB, Burgos NR, Witt WW, Barrett M (2012) Reducing the risks of herbicide resistance: best management practices and recommendations. Weed Sci 60(Spec. Issue), 31-62

Refsell DE, Hartzler RG (2009) Effect of tillage on common waterhemp (Amaranthus rudis) emergence and vertical distribution of seed in the soil. Weed Technol 23:129-133

Rosenbaum KK, Bradley KW (2013) A survey of glyphosateresistant waterhemp (Amaranthus rudis) in Missouri soybean fields and prediction of glyphosate resistance in future waterhemp populations based on in-field observations and management practices. Weed Technol 27:656-663

Schultz JL, Myers DB, Bradley KW (2015) Influence of soybean seeding rate, row spacing, and herbicide programs on the control of resistant waterhemp in glufosinate-resistant soybean. Weed Technol 29:169-176

Schwartz LM, Norsworthy JK, Young BG, Bradley KW, Kruger GR, Davis VM, Steckel LE, Walsh MJ (2016) Tall waterhemp (Amaranthus tuberculatus) and Palmer amaranth (Amaranthus palmeri) seed production and retention at soybean maturity. Weed Technol 30:284-290 
Spaunhorst DJ, Bradley KW (2013) Influence of dicamba and dicamba plus glyphosate combinations on the control of glyphosate-resistant waterhemp (Amaranthus rudis). Weed Technol 27:675-681

Spaunhorst DJ, Siefert-Higgins S, Bradley KW (2014) Glyphosate-resistant giant ragweed (Ambrosia trifida) and waterhemp (Amaranthus rudis) management in dicambaresistant soybean (Glycine max). Weed Technol 28: 131-141

Steckel LE, Sprague CL, Hager AG, Simmons FW, Bollero GA (2003) Effects of shading on common waterhemp (Amaranthus rudis) growth and development. Weed Sci 51:898-903

Steckel LE, Sprague CL, Stoller EW, Wax LM, Simmons FW (2007) Tillage, cropping system, and soil depth effects on common waterhemp (Amaranthus rudis) seed-bank persistence. Weed Sci 55:235-239

Van Wychen L (2016) National Weed Survey. http://wssa.net. Accessed January 7, 2017
Ward SM, Webster TM, Steckel LE (2013) Palmer amaranth (Amaranthus palmeri). Weed Technol 27:12-27

Webster TM, Grey TL (2015) Glyphosate-resistant Palmer amaranth (Amaranthus palmeri) morphology, growth, and seed production in Georgia. Weed Sci 63:264-272

Wiggins MS, Hayes RM, Steckel LE (2016) Evaluating cover crops and herbicides for glyphosate-resistant Palmer amaranth (Amranthus palmeri) control in cotton. Weed Technol 30: 415-422

Wiggins MS, McClure MA, Hayes RM, Steckel LE (2015) Integrating cover crops and POST herbicides for glyphosateresistant Palmer amaranth (Amaranthus palmeri) control in corn. Weed Technol 29:412-418

Received February 6, 2017, and approved April 7, 2017.

Associate Editor: Mark VanGessel, University of Delaware. 